\title{
Editorial: Uma homenagem à carreira do Prof. Sergio Araki
}

\author{
Araki SY§, Fujita IK§ e Bock EGP§ \\ §Laboratório de Bioengenharia e Biomateriais, Instituto Federal de São Paulo, Brasil.
}

Editorial. Quando nos propuseram escrever este editorial para a quarta edição da revista TASJ, ficamos diante de um desafio. Desde setembro de 2019, as expectativas estavam grandes para a realização do $5^{\circ} \mathrm{MECF}$ sob a presidência de uma mulher e com aspectos de internacionalização que o congresso, desde sua concepção, sonhou. Isso tudo iria se realizar em tão pouco tempo, apenas na quinta edição. Dentro destas expectativas, estavam as inscrições de um maior número de trabalhos segundo as prospecções de época. Entretanto, a pandemia global de Covid19 levounos rapidamente a uma reorganização em todos os aspectos. Por exemplo, no lugar da busca de garantias de espaços para a realização das sessões, nossa busca foi por garantir que o evento acontecesse de alguma forma. Neste sentido houve iniciativas muito interessantes e proveitosas como o Encontro Virtual de Iniciação Científica (EVIC) promovido pelo Instituto Federal de Educação, Ciência e Tecnologia de São Paulo - campus São Paulo (IFSP) e o Instituto Federal de Educação, Ciência e Tecnologia do Paraná - campus Foz do Iguaçu (IFPR) em junho de 2020. Mas o $5^{\circ}$ MEC3F 2020, com todas as sonhadas melhorias, não aconteceu.

Em um ano em que a ciência foi o assunto mais comentado, valorizado e divulgado de diferentes modos, as distâncias foram vencidas com a utilização de formatos remotos ou virtuais, podemos dizer que, de alguma forma, saímos fortalecidos nas relações humanas.

Há que se destacar, também, que neste ano, um dos fundadores do congresso MEC3F está se aposentando (Prof. Sergio Yoshinobu Araki). Um homem inspirador que sempre foi e será impulsionador de ideias, honrado e apoiador de inciativas científicas ousadas e com um valor humano inconfundível. Sem ele, não alcançaríamos as metas do MEC3F com tanta rapidez. É um amigo inseparável!

A seguir, apresentamos um breve relato pessoal do Prof. Araki: "Poxa, 42 anos dedicados ao ensino, não é pouco tempo, mas, foram muito bem vividos e aproveitados. O início de tudo, aos 21 anos, quando consegui um estágio em janeiro de 1978 na COFAP, para preparar material de apoio para treinamento dos funcionários, 30 dias após, por sorte, uma vaga apareceu e fui efetivado como instrutor de treinamento. A paixão pelo ensino foi imediata. Um ano após, por processo seletivo, já formado, mas no início da carreira em escola técnica, no Liceu de Artes e Ofícios de São Paulo, era janeiro de 1979, lecionando por 13 anos, com muitas saudades dos alunos e colegas professores, das gincanas organizadas por nossas orientadoras, ainda hoje mantenho contato com alunos formandos desta época. No mesmo período, início de 1983, tem o 
início das minhas atividades de professor na ETE Getúlio Vargas, lecionando também na ETE Lauro Gomes e ETE Jorge Street, onde conheci vários colegas professores que também lecionavam na Escola Técnica Federal, onde trabalhei por 18 anos. Em 1989, prestei o concurso da "federal" e acabei assumindo o cargo no final do mesmo ano, ficando por 30 anos e 8 meses como professor, nos cursos de Ensino Técnico Mecânica, Ensino Técnico Subsequente, Ensino Tecnológico e Engenharias, entrei no Regime de Dedicação Exclusiva e minha dedicação à escola foi completa, participei de vários projetos e comissões, fui coordenador de área, orientei vários alunos em projeto de IC, várias orientações de TCC, por muito tempo fui orientador de estágio. ...ahh não esquecendo das muitas viagens técnicas com os alunos de todos os cursos da nossa área, importante na minha vida e na vida dos alunos, sendo uma experiência de vida para todos, tendo sempre a companhia de colegas parceiros irmãos por um tempo precioso de pelo menos 10 anos, os Professores Eduardo Bock e Isac Fujita fiz várias amizades com alunos na qual mantenho contato, minha vida de docente foi muito feliz e prazerosa, alguns entraves, mas nada que me tirasse do rumo como professor. Agradeço a todos que, direta ou indiretamente, participaram da minha vida de docência, e espero estar presente na vida de alguns colegas e ex-alunos nesta nova etapa da minha vida. Estou e estarei sempre presente na vida de vocês que ainda de algum modo necessitarem da minha ajuda ou conversa em qualquer momento na vida de vocês".

Novos desafios, novas habilidades, novas fronteiras onde o homem jamais esteve! Juntos encontraremos respostas para o bem comum, através da ciência.

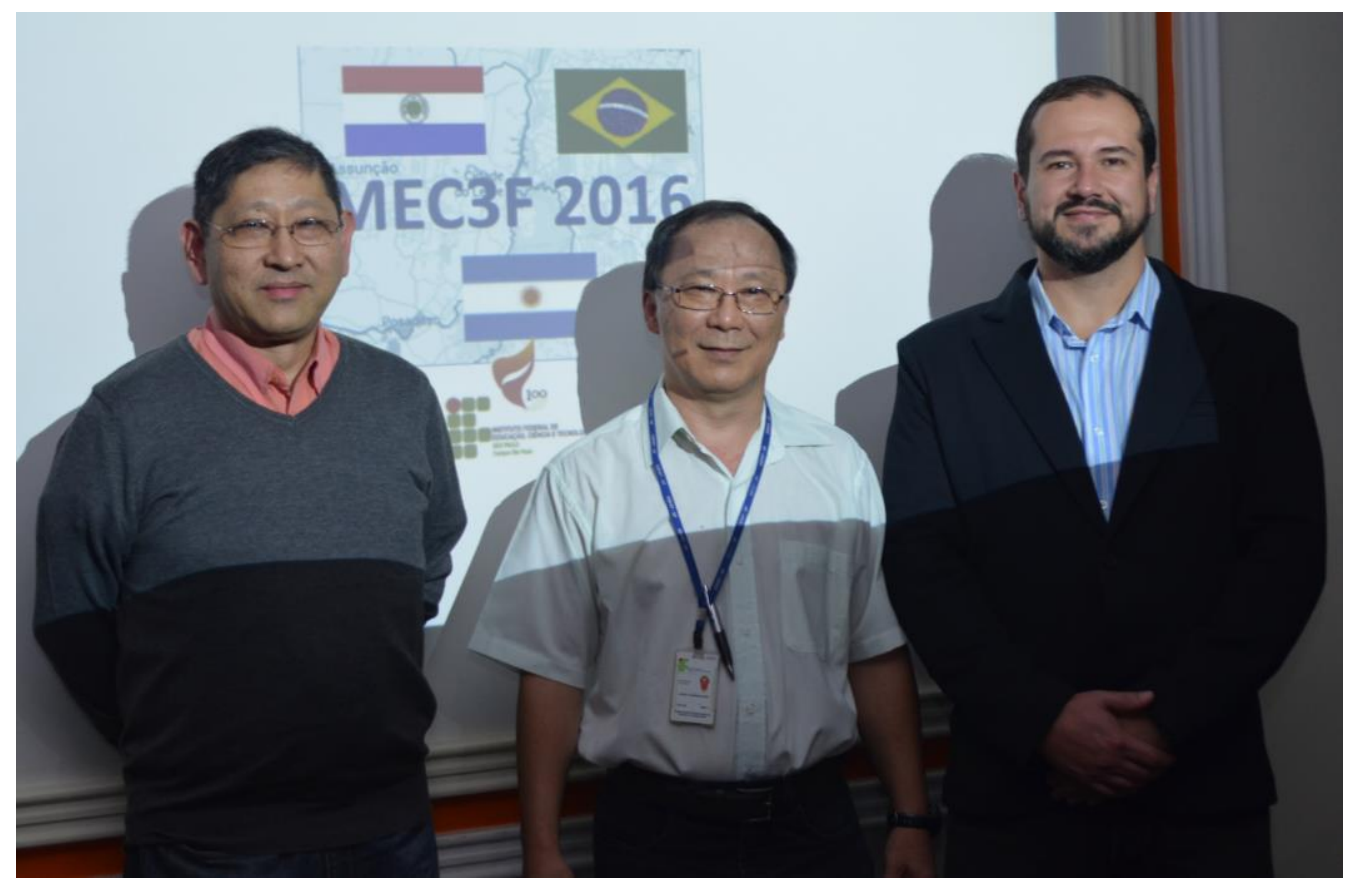

Muito obrigado a todos! 